\title{
Kombinasi feses sapi dan babi sebagai sumber biogas
}

\author{
D.K.P. Suriman, J.E.M. Soputan*, J.A.D. Kalele, V.R.W. Rawung \\ Fakultas Peternakan Universitas Sam Ratulangi Manado, 95115 \\ *Korespondensi (corresponding author) Email: jeanettesoputan@ymail.com
}

\begin{abstract}
ABSTRAK
Penelitian ini telah dilakukan dengan tujuan untuk mengetahui produksi biogas yang dihasilkan dari pemanfaatan feses sapi dan babi. Penelitian ini sudah dilakukan di Rumah Potong Hewan Bailang, Manado, Sulawesi Utara. Bahan utama yang digunakan dalam penelitian ini adalah menggunakan kombinasi feses sapi, feses babi dan air. Perbandingan kombinasi feses (feses sapi 2 ember, feses babi 1 ember dan air sebanyak 3 ember adalah 1:1. Peralatan yang digunakan adalah digester tipe horizontal, meteran, thermometer, indikator $\mathrm{pH}$, kompor biogas, selang, tong dan ember. Model analisis data yang akan digunakan yaitu adalah analisis deskriptif. Variabel yang diamati dalam penelitian ini adalah volume biogas, temperature, nilai $\mathrm{pH}$, serta aplikasi penggunaan biogas. Hasil peneltian selama 31 hari menunjukan bahwa total volume biogas yang dicapai sebanyak $122.266,262 \mathrm{~m}^{3}$. Hasil penelitian juga memperoleh rata-rata temperatur $31^{\circ} \mathrm{C}$ untuk di pagi hari dan $30^{\circ} \mathrm{C}$ untuk di sore hari. Nilai $\mathrm{pH}$ dari penelitian ini 7 . Pengujian gas dilakukan dua kali yaitu pertama pada hari ke 15 . Pengujian kedua dilakukan pada hari ke 31. Penggunaan biogas diperlukan waktu selama 24 menit untuk memasak. Kesimpulan dari penelitian ini adalah kombinasi feses sapi dan babi dengan temperatur $30-31^{\circ} \mathrm{C}$ dan $\mathrm{pH} 7$ menghasilkan biogas sebanyak $122.266,262 \mathrm{~cm}^{3}$ dengan waktu memasak sebanyak 24 menit.
\end{abstract}

Kata Kunci: biogas, feses sapi, feses babi,

\begin{abstract}
THE COMBINATION OF COW AND PIG FECES AS BIOGAS SOURCES. This research has been carried out with the aim to find out the biogas production produced from the use of cow and pig feces. This research was conducted at Bailang Abattoir Manado, North Sulawesi. The material used in this study were cow feces, pig feces and water. Comparison of feces combinations ( 2 bucket cow feces, 1 bucket pig feces and 3 bucket water was 1: 1). The equipment used is a horizontal type digester, measuring, thermometer, $\mathrm{pH}$ indicator, biogas stove, hose, barrel and bucket. The data analysis used was in this study was descriptive analysis. The variables observed in this study were biogas volume, temperature, $\mathrm{pH}$ value, and biogas application. The 31 days of research showed that the total volume of biogas achieved was $122,266,262 \mathrm{~m} 3$. The results also obtained an average temperature of $31^{\circ} \mathrm{C}$ for the morning and $30^{\circ} \mathrm{C}$ for the afternoon. The $\mathrm{pH}$ value of this study 7 . The gas test was conducted twice, first on the 15 th day. The second test was carried out on day 31. The use of biogas takes 24 minutes to cook. The conclusion of this study is the combination of cow and pig feces with a temperature of $30-31^{\circ} \mathrm{C}$ and $\mathrm{pH}$ 7 produces $122,266,262 \mathrm{~cm}^{3}$ of biogas with a cooking time of 24 minutes.
\end{abstract}

Keywords: biogas, cow feces, pig feces

\section{PENDAHULUAN}

Peternakan rakyat di Indonesia, kebanyakan memilih untuk membangun sebuah usaha peternakan di dekat sungai, 
danau, rawa-rawa, maupun didekat selokan yang intinya berdekatan dengan sumber air. Tujuan tersebut dibuat untuk memudahkan dalam proses pembersihan kandang maupun air minum bagi ternak. Kurangnya pengetahuan tentang pemanfaatan kotoran ternak, membuat masyarakat tidak peduli akan hal itu. Padahal banyak sekali manfaat yang bisa didapat dari kotoran tersebut contohnya adalah biogas (Damanik et al., 2014).

Menurut Sabatini 2017, pemanfaatan limbah sebagai sumber energi alternatif belum dimanfaatkan dengan baik, terutama limbah yang bersumber dari kegiatan peternakan dengan kapasitas yang besar. Untuk itu, limbah yang dibuang ke lingkungan mempunyai sifat dan karateristik tertentu dan cukup potensial menimbulkan dampak merugikan pada lingkungan sehingga perlu dilakukan penanganan kembali.

Permintaan kebutuhan Bahan Bakar Minyak (BBM) di Indonesia baik itu untuk keperluan industri, transportasi dan rumah tangga dari tahun ke tahun semakin meningkat. Hal ini menyebabkan ketersediaan energi minyak bumi menjadi langka dan harganya melambung tinggi. Pemerintah Indonesia pun mulai mencari terobosan baru dalam menciptakan energi alternatif yang jauh lebih murah pengganti energi minyak bumi. Dengan adanya energi alternatif, penggunaan energi yang tak terbarukan semakin berkurang.

Pemanfaatan biogas di Indonesia sebagai energi alternatif sangat memungkinkan untuk diterapkan di masyarakat, apalagi sekarang ini harga bahan bakar minyak yang makin mahal dan kadang-kadang langka keberadaannya. Besarnya potensi limbah biomassa padat diseluruh Indonesia adalah 49.8077,43 MW (Sabatini, 2017). Biomassa seperti kayu, dari kegiatan industri pengolahan hutan, pertanian dan perkebunan, limbah kotoran hewan, misalnya kotoran sapi, kerbau, kuda, dan babi juga dijumpai di seluruh provinsi Indonesia dengan kualitas yang berbeda-beda. Pada saat ini sebagai sumber bahan baku biogas tersedia secara melimpah dan belum dimanfaatkan secara maksimal (Andreas et al., 2012).

Biogas merupakan renewable energy yang dapat dijadikan bahan bakar alternatif untuk menggantikan bahan bakar yang berasal dari fosil seperti minyak tanah dan gas alam. Akhir-akhir ini diverifikasi penggunaan energi menjadi isu yang sangat penting karena berkurangnya sumber bahan baku minyak (Dharma dan Ridhuan, 2014). Pemanfaatan limbah pertanian untuk memproduksi biogas dapat memperkecil konsumsi energi komersial seperti minyak tanah juga penggunaan kayu bakar (Wahyuni 2013). Penggunaan feses sapi dan babi dalam penelitian ini bertujuan untuk mengoptimalkan kondisi $\mathrm{C} / \mathrm{N}$ yang terkadung dalam kedua feses, melalui perhitungan yang akan digunakan dalam penelitian

\section{MATERI DAN METODE PENELITIAN}

\section{Lokasi dan waktu penelitian}

Penelitian ini sudah dilakukan di Rumah Potong Hewan Bailang, Kec. Tuminting Manado, Sulawesi Utara selama 1 bulan dari tanggal 28 November 2019 sampai 28 Desember 2019.

\section{Materi Penelitian \\ Bahan}

Bahan yang digunakan dalam penelitian ini adalah feses babi, feses sapi dan air.

Alat

Alat yang digunakan dalam penelitian ini adalah :

1. Satu unit penghasil biogas tipe horizontal mengacu pada Soputan (2012) yang terdiri dari :

a. 1 Unit drum digester dan 1 unit drum penampung gas.

b. Selang berdiameter $3 / 4 \mathrm{~cm}$ sepanjang 3 $\mathrm{m}$.

c. Meteran, thermometer batang air raksa $100^{\circ} \mathrm{C}$, indikator $\mathrm{pH}$, selang 
plastic untuk mengalirkan gas, ember plastik dan kompor.

\section{Prosedur Penelitian \\ Penyiapan instalasi gas}

Instalasi gas yang digunakan adalah 2 unit drum berukuran 200 liter yang telah di bentuk menjadi digester dan tabung pengumpul gas kemudian disambung menggunakan selang antara digester dan pengumpul gas.

\section{Penyiapan bahan baku}

Bahan baku diambil di masing masing ternak kandang menggunakan sekop dan ember. Feses ternak sapi diambil di Rumah Potong Hewan Bailang, sedangkan feses ternak babi diambil dari peternakan rakyat yang berada di desa Tinoor. Perlakuan

Perlakuan dalam penelitian ini menggunakan kombinasi feses sapi, feses babi dan air. Perbandingan kombinasi feses (feses sapi 2 ember, feses babi 1 ember dan air sebanyak 3 ember adalah 1:1).

Perbandingan tersebut didasari oleh kondisi $\mathrm{C} / \mathrm{N}$ dan juga aktivitas mikroorganisme dari masing-masing feses. Diketahui $\mathrm{C} / \mathrm{N}$ ideal 30 . $\mathrm{C} / \mathrm{N}$ feses sapi sebesar 18; C/N feses babi sebesar 25 .

\section{Metode penelitian}

Pada Peneliian ini menggnakan analisis data deskriptif. Analisis deskriptif yaitu suatu bentuk penelitian yang ditunjukan untuk mendeskripsikan fenomena-fenomena yang ada, baik fenomena alamiah maupun fenomena buatan mausia. Fenomena itu bisa berupa bentuk, aktifitas, karateristik, perubahan hubungan, kesamaan, dan pebedaan antara fenomena yang satu dengan fenomena yang lainnya (Nasution, 2017).

Alur penelitian dapat dilihat pada Gambar 1. Pengukuran variabel dilakukan setiap hari sejak pemasukan bahan baku kedalam digester yaitu pada pagi hari dan sore hari.

\section{Variabel pengamatan Volume gas}

Volume gas yang dihasilkan dari limbah ternak babi, diukur setiap hari. Cara pengukuran dilakukan dengan cara mencatat langsung dari jumlah gas yang tertampung pada tabung penampungan gas dengan menggunakan rumus silinder (Soputan, 2012).

\section{Temperatur}

Pengukuran temperatur dilakukan dengan menggunakan thermometer berskala celcius. Pengukuran temperatur dilakukan setiap hari meliputi pengukuran bagian dalam dan diluar digester (Soputan, 2012).

pH

Pengukuran $\mathrm{pH}$ dilakukan dengan menggunakan $\mathrm{pH}$ indikator (Soputan, 2012).

\section{Aplikasi dan pengukuran biogas}

Pada tahap akhir dilakukan percobaan biogas untuk memasak dan mencatat waktu dan penggunaan biogas. Selama retensi waktu 31 hari, pengujian/pengaplikasian biogas dilakukan 2 kali, pengujian pertama dilakukan tes yaitu pada hari ke 14 dan pengujian yang kedua dilakukan pada hari ke 31. Pengujian dilakukan dengan menggunakan selang

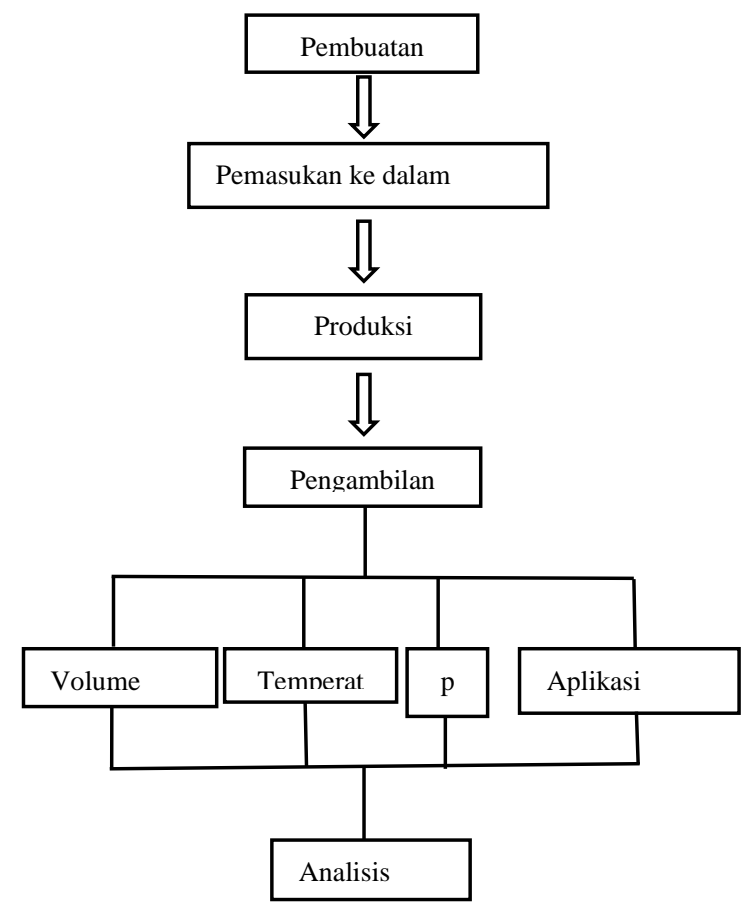

Gambar 1. Skema Alur Penelitian 
yang di sambung ke kran pengeluaran biogas dan menggunakan kompor yang sudah di rancang untuk biogas, dimana lubang untuk aliran gas pada kompor di perbesar mengingat tekanan biogas yang begitu kecil jika dibandingkan dengan gas elpiji.

\section{HASIL DAN PEMBAHASAN}

\section{Volume Biogas}

Proses pembentukan biogas dipengaruhi oleh tersedianya bahan organik dalam substrat $\mathrm{C} / \mathrm{N}$ dan aktifitas mikroorganisme (Utomo dan Wahyuningsih, 2010). Ratio $\mathrm{C} / \mathrm{N}$ dalam bahan organik sangat mempengaruhi kegiatan mikroorganisme dalam memproduksi gas bio. Bila $\mathrm{C} / \mathrm{N}$ terlalu tinggi populasi dan aktivitas mikroorganisme rendah dan akibatnya produksi gas bio menjadi rendah atau mungkin tidak terbentuk sama sekali dan apabila $\mathrm{C} / \mathrm{N}$ terlalu rendah akan mengurangi nitrogen yang akan berubah menjadi ammonia dan meracuni bakteri. (Utomo dan Wahyuningsih, 2010). Biogas memliki berat $20 \%$ lebih ringan dibandingkan dengan udara dan memiliki nilai panas pembakaran antara 4800-6200 $\mathrm{kkal} / \mathrm{m} 3$. Nilai ini sedikit lebih rendah dari nilai pembakaran gas metana murni yang mencapai $8900 \mathrm{kkal} / \mathrm{m} 3$ (Utami et al., 2017).

Produksi gas bio juga dipengaruhi oleh suhu lingkungan, kondisi temperatur yang ideal sangat dibutuhkan untuk aktivitas mikroorganisme dan juga proses fermentasi. Aktivitas normal dari mikroba metan membutuhkan sekitar $90 \%$ air dan 7$10 \%$ bahan kering dari bahan masukan untuk fermentasi. Dengan demikian isian yang paling banyak menghasilkan biogas adalah yang mengandung $7-9 \%$ bahan kering. Untuk kandungan kering sejumlah tersebut bahan baku isian biasanya dicampur dengan air dengan perbandingan tertentu (Wiratmana et al., 2012). Fermentasi dapat berlangsung bila suhu lingkungan dan suhu digester berkisar antara $5-55^{\circ} \mathrm{C}$, dan suhu digester yang ideal adalah antara $32-35^{\circ} \mathrm{C}$ (Sihombing, 1997). Selain di pengaruhi oleh faktor $\mathrm{C} / \mathrm{N}$ dan juga temperatur, aktivitas mikroorganisme dan proses fermentasi juga dipengaruhi oleh kondisi $\mathrm{pH}$ dalam digester (Saputra et al., 2010).

Setelah mencapai puncak produksi, gas akan terjadi penurunan secara gradual. Hal ini disebakan oleh penurunan komponen bahan organik yang telah mengalami degradasi menjadi komponen lain mengakibatkan kinerja/aktivitas bakteri metanogenik menurun (Mara, 2012).

Data hasil pengamatan volume gas dapat dilihat pada Gambar 2. Volume gas pada hari ke 1 sampai hari ke 5 menunjukan tidak ada perubahan signifikan dari tong disebabkan belum ada gas yang terbentuk dalam retensi hari tersebut. Hal tersebut terjadi karena pada retensi hari tersebut adalah proses hidrolisis dan juga proses pengasaman. Menurut Anggraeni et al. (2013) proses hidrolisis akan berlangsung sekitar 6 sampai 8 jam dengan kondisi temeratur di atas $80^{\circ} \mathrm{C}$ hingga $110^{\circ} \mathrm{C}$. Pada penelitian ini proses hidrolisis berada pada suhu $30^{\circ} \mathrm{C} \quad 35^{\circ} \mathrm{C}$ untuk menjaga keberlangsungan hidup bakteri metan.

Pada hari ke 6 biogas mulai terbentuk dan membuat tong penampungan biogas terangkat hingga hari ke 14. Pada penelitian ini, di hari ke 14 biogas akan di buang dengan tujuan untuk membuang gas metan yang masih tercampur dengan berbagai gas lainnya yang membuat gas tidak menyala.

Pada hari ke 15 gas mulai terbentuk kembali dan tong terus naik dengan titik puncak tertinggi pada hari ke 28 dengan tinggi $46,3 \mathrm{~cm}$ dan volumenya sebesar $122.266,262 \mathrm{~cm}^{3}$. Menurut Dharma dan Ridhuan (2014), bahwa produksi tertinggi biogas pada suhu $30^{\circ} \mathrm{C}$ terdapat pada $\mathrm{C} / \mathrm{N}$ 25 dengan rata-rata memproduksi gas sebesar $12,75 \mathrm{~mL}$ per $20 \mathrm{~mL}$ substrat. Produksi terendah terdapat pada C/N 20 yaitu memiliki rata-rata sebesar $8 \mathrm{~mL}$ per 


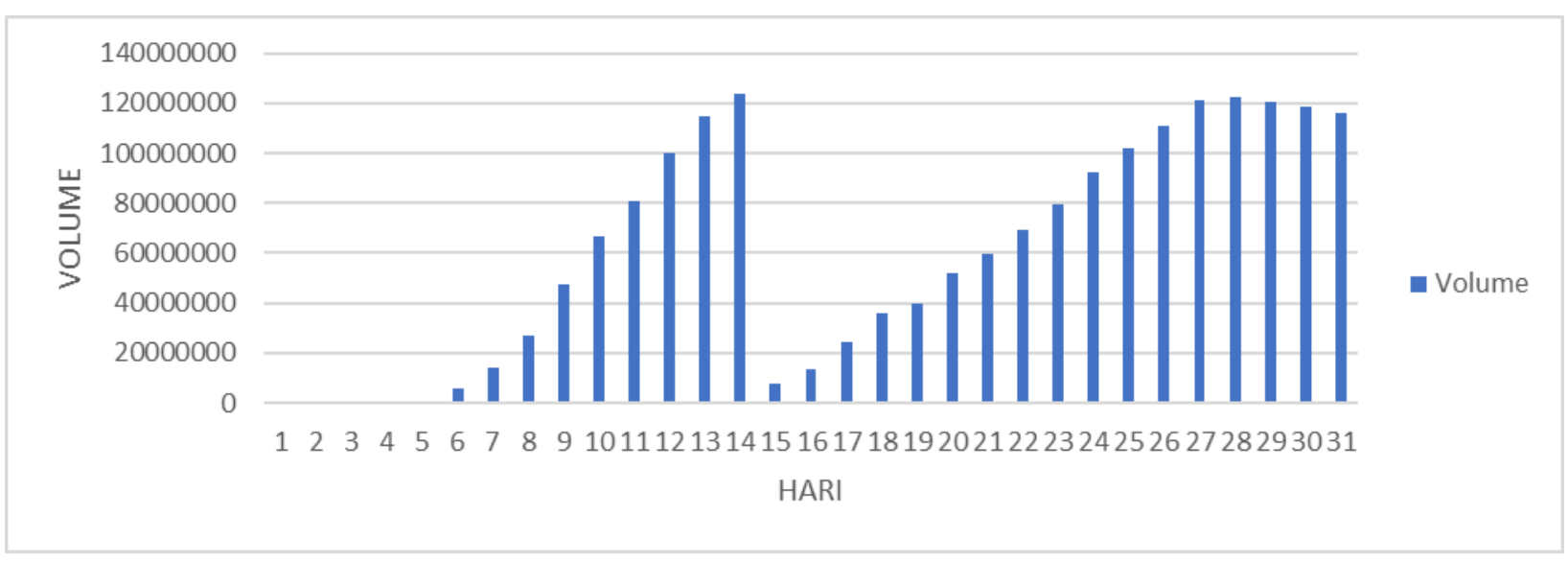

Gambar 2. Volume Gas

$20 \mathrm{~mL}$ substrat. Menurut Takarenguang (2015), tinggi tong penampung biogas dengan prosedur yang sama dapat mencapai $57,5 \mathrm{~cm}$ dengan volume biogas $151.842 \mathrm{~m}^{3}$ dengan puncak tertinggi tong, dengan menggunakan feses ternak babi bibit. Hal ini disebabkan oleh bahan utama yang digunakan adalah feses ternak babi, dimana feses ternak babi memiliki kadar $\mathrm{C} / \mathrm{N}$ yang lebih tinggi dibandingkan feses sapi (Sihombing, 1997). Fakta menunjukan bahwa perlakuan dengan salah satu bahan (feses) yang banyak memiliki kecendrungan produksi gas bio yang relativ lebih banyak (Utomo dan Wahyuningsih, 2010). Hasil ini hampir mendekati penelitian dari Soputan (2012), dimana tong penampung biogasnya dapat mencapai $49 \mathrm{~cm}$ dengan volume 129.396,26 $\mathrm{cm}^{3}$ dengan prosedur yang sama dengan menggunakan bahan utama yaitu feses ternak sapi. Pada hari ke 29 terjadi penurunan, hal ini disebakan oleh penurunan kinerja/aktivitas bakteri anaerob, dengan adanya penurunan bahan organik yang telah mengalami degradasi menjadi komponen lain. Menurut Basuki et al. (1990) puncak produksi gas bio yaitu bahwa puncak produksi gas bio dicapai pada hari ke 21-25 dan setelah mencapai puncak produksi gas bio akan menurun secara gradual. Pada hari ke 30 gas bio masih tetap berproduksi ini dimungkinkan karena masih adanya substrat yang dapat digunakan untuk proses pembentukan biogas, shingga proses fermentasi tetap berlangsung.

\section{Temperatur}

Temperatur optimal untuk pencerna anaerob adalah pada $30-35^{\circ} \mathrm{C}$. Temperatur dapat dilihat pada Gambar 3. Kisaran temperatur ini mengkombinasikan kondisi terbaik untuk pertumbuhan bakteri dan produksi gas metan di dalam digester dengan lama proses yang pendek. Masa bahan yang sama akan dicerna dua kali lebih cepat pada temperature $35^{\circ} \mathrm{C}$ dibanding $15^{\circ} \mathrm{C}$ dan menghasilkan hamper 15 kali lebih banyak gas pada waktu proses yang sama.

Pada gambar 3, suhu di pagi hari pukul 10.00 dengan kisaran suhu $26^{\circ} \mathrm{C}$ $36^{\circ} \mathrm{C}$ dengan rata-rata suhu $31^{\circ} \mathrm{C}$ cendrung lebih tinggi jika dibandingkan dengan suhu disore hari pada pukul 17.00 yaitu berkisar antara $25^{\circ} \mathrm{C}-34^{\circ} \mathrm{C}$ dengan rata-rata suhu $30^{\circ} \mathrm{C}$. Jika dibandingkan dengan penelitian sebelumnya, maka rata-rata suhu yang didapatkan layak untuk proses fermentasi/aktivitas mikroorganisme dalam membentuk biogas. Hasil penelitian Saputra et al. (2010) mendapati temperatur lingkungan, pagi $27,25^{\circ} \mathrm{C}$, siang $31,08^{\circ} \mathrm{C}$ dan di sore hari $29,15^{\circ} \mathrm{C}$. Dari hasil tersebut didapati bahwa kondisi temperatur 


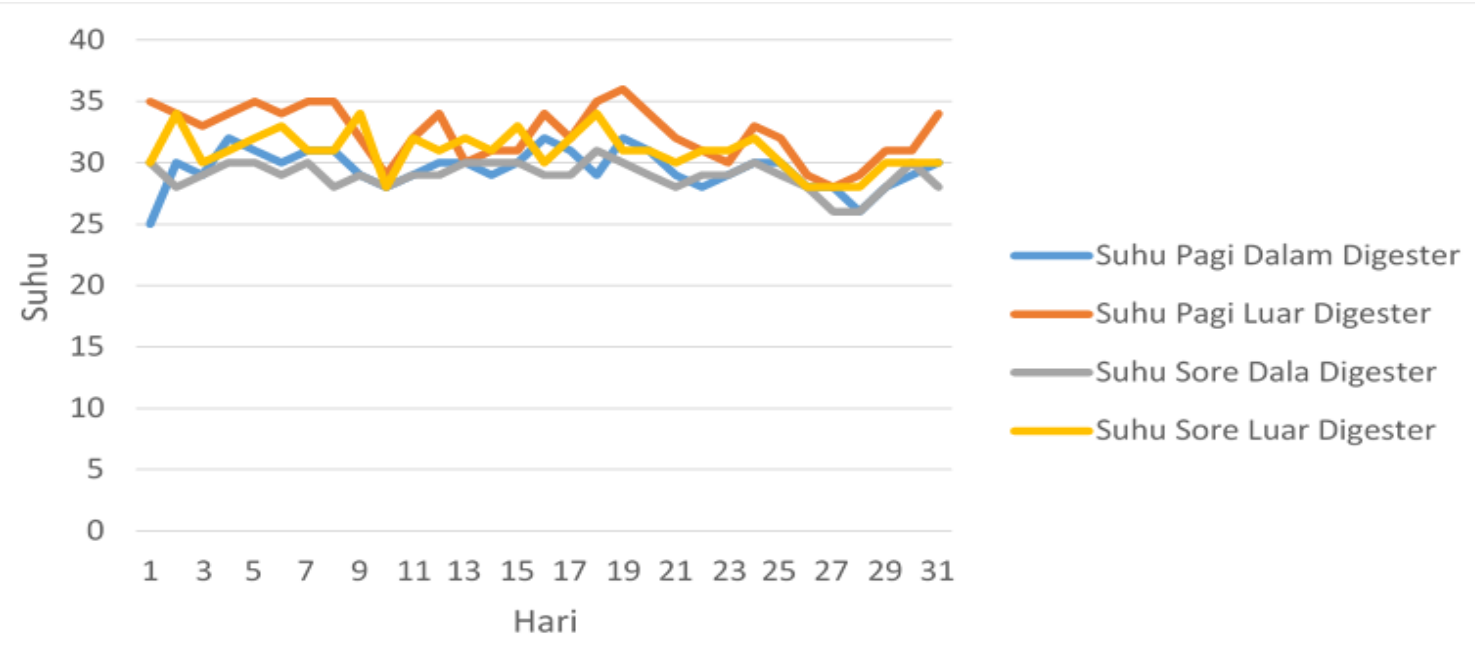

Gambar 3. Data hasil pengukuran temperatur/suhu

lingkungan kurang optimal karena temperatur optimal berkisar antara 32 $35^{\circ} \mathrm{C}$, sehingga proses degradasi danpembentukan asam organik dan pembentukan metan kurang maksimal.

Menurut Sihombing

(1997)

mengatakan, fermentasi dapat berlangsung bila suhu digester berkisar antara $5-55^{\circ} \mathrm{C}$, dengan suhu ideal digester yaitu berkisar antara $32-35^{\circ} \mathrm{C}$.

\section{Derajat Keasaman (pH)}

Aktifitas mikroorganisme dibutuhkan kisaran pH $6-8$, sedangkan paling ideal adalah 7,4. Fermentasi anaerob dapat bekerja dengan baik untuk menghasilkan gas bio secara optimal pada kisaran $\mathrm{pH}$ 6,8 -8 (Utomo dan Wahyuningsih, 2010). Pada pH dibawah 6,8 misalnya 6,2 aktivitas mikroorganisme metanogenik menurun sedang bakteri asetogenik yang menghasilkan asam asetat terus meningkat dan mengakibatkan produksi gas bio menurun (Sihombing, 1997).

Pada Gambar 4, pengukuran $\mathrm{pH}$ menggunakan $\mathrm{pH}$ indikator, hasil pengukuran stabil yaitu 7. Dari hasil pengukuran hari pertama mununjukan bahwa kondisi $\mathrm{pH}$ layak untuk fermentasi, hal ini menyebabkan proses fermentasi diawal dapat berjalan dengan baik dan juga optimal. Hasil peneltian ini berbanding terbalik dengan hasil penelitian Takarenguang et al. (2013), didapati pH awal berkisar antara 4-5. Penelitian ini sejalan dengan hasil penelitian Saputra et al. (2010) didapatkan kondisi $\mathrm{pH}$ dengan rata-rata 7 . Dengan $\mathrm{pH} 7$ memungkinkan untuk terjadinya proses fermentasi. Menurut Sihombing (1997) Kondisi pH di bawah 6 membuat aktivitas mikroorganisme metanogenik menurun dan bakteri asetogenik yang menghasilkan asam asetat terus meningkat dan mengakibatkan produksi gas menurun. Demikian pula dengan $\mathrm{pH}$ yang tinggi, menurut Hermawan et al. (2007), nilai pH yang tinggi akan menyebabkan produk akhir yang dihasilkan adalah $\mathrm{CO}_{2}$ sebagai produk utama.

\section{Aplikasi Penggunaan Biogas}

Aplikasi penggunaan biogas dapat dilihat pada Tabel 1. Tabel ini memperlihat seberapa banyak gas yang terpakai dan berapa lama waktu yang diperlukan untuk memasak. Pada pengujian pertama dilakukan tes pada hari ke 14 pada ketinggian tong $46,8 \mathrm{~cm}$ dengan volume tong sebesar $123.586,632 \mathrm{~cm}^{3}$. Pengujian ini belum terbentuk nyala api. Tidak terbentuknya nyala api disebabkan karena di dalam tong penampung masih tercampur dengan berbagai gas lainnya seperti 


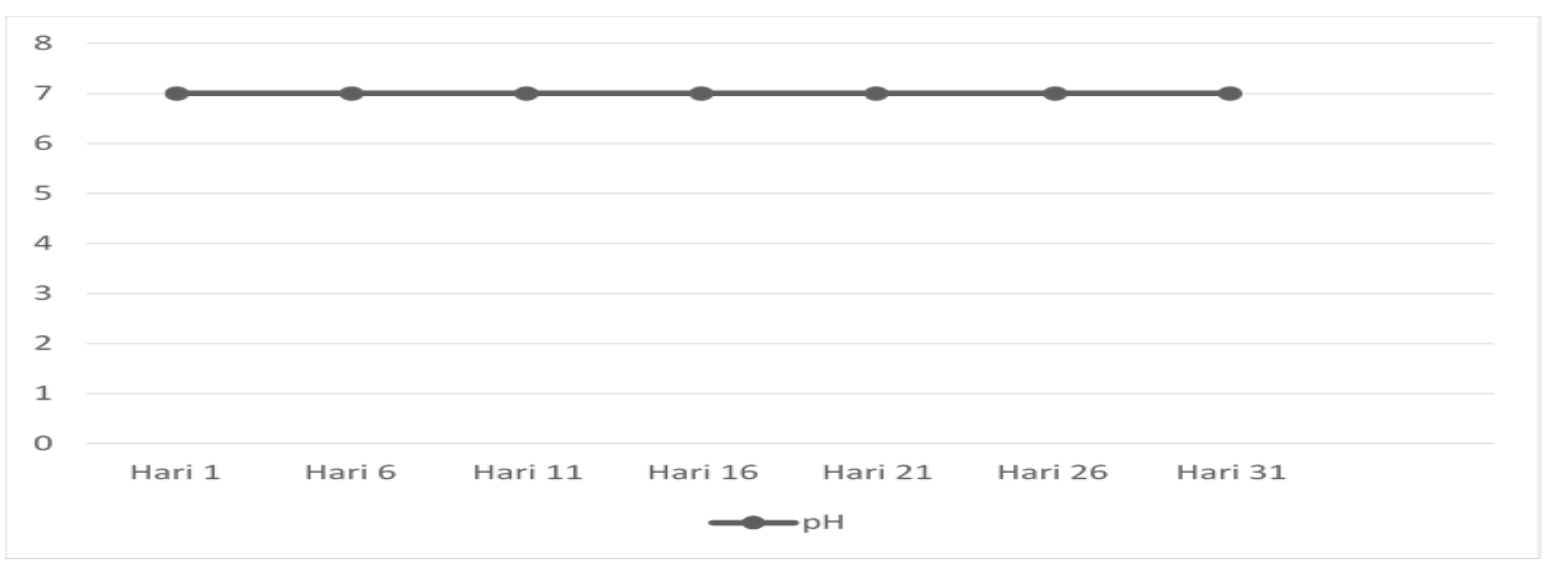

Gambar 4. Grafik penguuran pH.

Tabel 1. Aplikasi Penggunaan Biogas Dalam Memasak

\begin{tabular}{llcc}
\hline Kegiatan & Banyak Bahan & Biogas $\left(\mathrm{cm}^{3}\right)$ & Waktu (Menit) \\
\hline Goreng Telur & 1 Butir & $31.688,88$ & 6 \\
Rebus Mie (Air=200 mL) & 1 Bungkus & $25.087,03$ & 8 \\
Masak Air & 1 Liter & $30.368,51$ & 10 \\
\hline Total & & $87.144,42$ & 24 \\
\hline
\end{tabular}

hydrogen sulfida, kandungan air, karbondioksida. Menurut Kueain et al. (2007) bahwa apabila gas metan masih tercampur dengan gas lain dan gas tersebut masih tercium seperti bau blerang maka belum bisa menghasilkan nyala api.

Pengujian yang kedua dilakukan pada hari ke 31 dengan tinggi tong $44 \mathrm{~cm}$, dilengkapi peralatan kompor yang sudah di rancang untuk biogas, terbentuk nyala api yang dihasilkan berkualitas dan berwarna biru terang. Pengaplikasian dari hasil pengujian ini terdiri dari waktu yang dibutuhkan untuk menggoreng telur memerlukan 6 menit dan biogas yang digunakan sebanyak $31.688,88 \mathrm{~cm}^{3}$. Untuk merebus mie membutuhkan waktu 8 menit dan memerlukan biogas sebanyak 25.087,03 $\mathrm{cm}^{3}$ dan untuk merebus air membutuhkan waktu selama 9 menit dan biogas yang digunakan sebanyak 30.368,51 $\mathrm{cm}^{3}$. Dengan demikian bahwa total waktu yang dibutuhkan selama memasak adalah 24 menit dengan total gas yang digunakan sebanyak $87.144,42 \mathrm{~cm}^{3}$. Hasil pengujian ini masih lebih efisien dibandingkan dengan penelitian Takarenguang (2015) yakni waktu yang dibutuhkan untuk mendidihkan air, menggoreng telur dan memasak mie selama 24 menit dengan menghabiskan gas sebanyak - sebanyak 87.144,42 mL. Menurut Mirah et al. (2016) bahwa total lama nyala api yang diperlukan untuk memasak serta banyaknya gas yang terpakai tergantung dari besar kecilnya kran pengeluaran ketika dibuka pada saat penggunaan biogas.

\section{KESIMPULAN}

Kombinasi feses sapi dan babi dengan temperatur $30-31^{\circ} \mathrm{C}$ dan $\mathrm{pH} 7$ menghasilkan biogas sebanyak $122.266,262 \mathrm{~cm}^{3}$ dengan waktu memasak selama 24 menit. 


\section{DAFTAR PUSTAKA}

Andreas, F.S., S.B.U. Paramitha dan I. Diyono. 2012. Pembuatan biogas dari sampah sayuran. Jurnal Teknologi Kimia dan Industri 1(1): 103-108.

Anggraeni, P.; Z. Addarojah, D. D. Anggoro. Hidrolisis selulosa ecceng gondok (Eichhornia crassipe) menjadi glukosa dengan katalis arang aktif tersulfonasi. Jurnal Teknologi Kimia dan Industri 2(3): 63-69.

Basuki, P., G. Murjito dan N. Ngadiono. 1990. Hubungan Antara Umur Isian Bahan Baku Dengan Produksi Gas Bio Pada Kotoran Sapi Potong. Proyek peningkatan Perguruan Tinggi. Fakultas Peternakan, UGM. Yogyakarta.

Hermawan, B., L. Qodriyah dan C. Puspita. 2007. Pemanfaatan Sampah Organik sebagai Sumber Biogas Untuk Mengatasi Krisis Energi dalam Negeri. Universitas Lampung, Bandar Lampung.

Damanik, L.H, A.H. Husodo, T. Gunawan. 2014. Pemanfaatan feses ternak sapi sebagai energi alternatif biogas bagi rumah tangga dan dampaknya terhadap lingkungan. Jurnal Teknosains 4(1)

Dharma, S. U. dan K. Ridhuan. 2014. Kajian potensi sumber energi biogas dari kotoran ternak untuk bahan bakar alternatif di Kecamatan Kalirejo Kabupaten Lampung Tengah. Turbo: Jurnal Program Studi Teknik Mesin $3(2)$

Mara, I. M. 2012. Analisis penyerapan gas karbondioksida (CO2) dengan larutan naoh terhadap kualitas biogas kotoran sapi. Jurnal Keilmuan dan Terapan Mesin Teknik 2(1).

Mirah, A.D., J.E.M. Soputan, C.P. Paruntu. 2016. Feses ternak sapi sebagai penghasil biogas. Jurnal LPPM Bidang Sains dan Teknologi 3(1): 19.

Nasution, L.M. 2017. Statistik Deskriptif. Hikmah 14(1): 49-55
Saputra, T., S. Triatmojo, A. Pertiwiningrum. 2010. Produksi biogas dari campuran feses sapi dan ampas tebu (Bagasse) dengan rasio $\mathrm{C} / \mathrm{N}$ yang berbeda. Jurnal Ilmu Ternak 34(2): 114-122

Sabatini S., 2017. Biogas Babi Sebagai Bahan Bakar Pengganti Fosil yang Ramah Lingkungan di Kabupaten Samosir Sumatra Utara. Prosiding. Seminar Nasional III Biologi dan Pembelajarannya. Pp: 151-163

Sihombing, D. T. H. 1997. Ilmu Ternak Babi. IPB. Gadja Mada University Press.

Soputan, J. 2013. Pola Integrasi Ternak Babi dengan Tanaman Ubi Jalar yang Berwawasan Lingkungan di Minahasa. Disertasi. Program Pascasarjana, IPB. Bogor.

Takarenguang, E., J.M. Soputan, V.R.W. Rawung, J.A.D. Kalele. 2016. Pemanfaatan limbah babi bibit sebagai penghasil biogas. Jurnal Zootek 36(1): 113-122

Utami S. W., B. H. Sunarminto, E. Hanudin. Pengaruh limbah biogas sapi terhadap ketersediaan hara makro-mikro inceptisol. Jurnal Tanah dan Air 14(2): 50-59

Utomo, S. dan V. Wahyuningsih. 2010. Dosis campuran limbah sapi dan limbah babi terhadap produksi gasbio. Jurnal AgriSains 1(1)

Wahyuni S. 2013. Panduan Praktis Biogas. Bogor: Penebar Swadaya.

Y.A. Kueain, I. K. Suamba, P.U. Widjayanti. 2017. Analisis Finansial Usaha Peternakan Babi (Studi Kasus Peternakan Babi UD Karang di Desa Jagapati, Kecamatan Abiansemal, Kabupaten Badung). Jurnal Agribisnis dan Agrowisata 6(1): 96104

Wiratmana, I., P. Awing, I. Sukadana, G. Ketut, I. Tenaya dan G.N. Putu. 2012. Studi eksperimental pengaruh variasi bahan kering terhadap produksi dan nilai kalor biogas kotoran sapi. Jurnal Energi dan Manufaktur 5(1): Pp 1-97. 